\begin{tabular}{lllllllll}
$\mathbf{A}$ & $\mathbf{R}$ & $\mathbf{T}$ & $\mathbf{Y}$ & $\mathbf{K}$ & $\mathbf{U}$ & $\mathbf{L}$ & $\mathbf{Y}$ \\
\hline
\end{tabular}

ROCZNIKI NAUK SPOEECZNYCH

Tom 11(47), numer 3 - 2019

DOI:http://dx.doi.org/10.18290/rns.2019.11.3-1

\title{
HISTORYCZNE UWARUNKOWANIA \\ DZIAŁAŃ BIZNESOWYCH W POLSCE \\ Z PERSPEKTYWY KONCEPCJI PRZESTRZENI SPOŁECZNEJ
}

\section{WPROWADZENIE}

W latach 50. XX wieku Chombart de Lauwe ${ }^{1}$ sugerował, by przestrzeń społeczną (l'espace social) postrzegać jako obszar czy też ramę, w obrębie której subiektywne oceny i motywy działań aktorów społecznych (jednostek i zbiorowości) powinno się rozpatrywać w odniesieniu do konkretnych działań realizowanych pod wpływem określonych czynników ekologicznych, kulturowych i socjoekonomicznych. Inny znany francuski socjolog i filozof - Henri Lefebvre - podkreślał, że w obrębie ludzkich społeczności „każda przestrzeń ma społeczny charakter, ponieważ jej istota leży w przyporządkowaniu mniej lub bardziej odpowiednich miejsc określonym stosunkom społecznym [...] w tym sensie przestrzeń społeczna jest produktem społecznym"”. W takim ujęciu przestrzeń społeczna jest metaforą realnego doświadczania życia społecz-

Dr WALDEMAR DYMARCZYK - Instytut Socjologii Uniwersytetu Łódzkiego; adres do korespondencji: ul. Rewolucji 1905 r. 41/43, 90-214 Łódź; e-mail: dymarczyk.waldemar@ gmail.com; ORCID: https://orcid.org/0000-0002-2343-9943.

${ }^{1}$ Ch. De Lauwe i in., Paris et l'agglomération parisienne, Paris: Presses Universitaires de France 1952; Ch. De Lauwe, H. PAUl, La vie quotidienne des familles ouvrères, Paris: Presses Universitaires de France 1956.

${ }^{2}$ H. Lefebvre, State, Space, World: Selected Papers, Minneapolis: Minnesota University Press 2009, s. 186-187. 
nego, w którym z jednej strony działania jednostek i grup podlegaja presji otoczenia/środowiska (milieu), z drugiej zaś to samo środowisko może stanowić dla aktorów społecznych bezpieczny, intymny punkt oparcia (ambience) ${ }^{3}$ lub być źródłem niepokoju czy niepewności. W tej optyce „przestrzeń społeczna niweluje dychotomię pomiędzy przestrzenią «prywatną» a "publiczną» [...] oraz kieruje uwage na subiektywne i fenomenologiczne jej postrzeganie"4.

W perspektywie przyjętej przez Lefebvre'a przestrzeń społeczna jest przede wszystkim ,pojemnikiem stosunków społecznych, naczyniem gromadzącym ślady historii («wyniki przeszłych działań»). Fizyczna przestrzeń bierze bowiem udział $\mathrm{w}$ dialektycznej wymianie $\mathrm{z}$ ludźmi, trwającej poprzez historię" ${ }^{5}$. Przestrzeń przybiera zatem formę charakterystyczną dla określonych stosunków reprodukcji (relacji pomiędzy płciami, grupami wieku, relacjami powinowactwa i pokrewieństwa) i stosunków produkcji (podziału pracy i sposobów jej organizowania) ${ }^{6}$, a jednocześnie produkuje społeczeństwo, wpływając na charakter relacji społecznych. Tak więc każde społeczeństwo na każdym etapie rozwoju wykształca własne praktyki przestrzenne, które odwzorowują wspomniane sposoby produkcji i reprodukcji, „w toku zaś tych praktyk ludzie wytwarzają swoja przestrzeń, naznaczają ją i przyswajają"7. Przyjmuja wobec tej przestrzeni określone postawy i wyrażają określone uczucia i emocje. Każda grupa społeczna stara się kształtować przestrzeń, w której żyje i z którą chce się identyfikować w taki sposób, by jak najlepiej wyrażała ona system wartości tej grupy. Na przykład, Mircea Eliade zauważył, że „człowiek religijny ciagle stara się znaleźć «w centrum świata». Aby móc żyć w świecie, trzeba go ustanowić - żaden świat nie powstanie zaś w «chaosie» homogeniczności i względności przestrzeni świeckiej. Odkrycie i wyprojektowanie punktu stałego, «centrum», jest podobne do stworzenia świata”. Takim „mocnym”, „stałym punktem oparcia” była niewątpliwie średniowieczna strzelista katedra umieszczona w sercu miasta, „która oferuje

${ }^{3}$ J. O’NeILL, Sociology as a Skin Trade: Essays Towards a Reflexive Sociology, New York: Harper \& Row 1972, s. 174.

${ }^{4}$ P. Smethurst, The Postmodern Chronotype: Reading Space and Time in Contemporary Fiction, Amsterdam-Atlanta: Rodopi B.V. 2000, s. 44.

${ }^{5}$ A. MAJER, Od idei przestrzeni spotecznej do koncepcji czasoprzestrzeni, w: A. MAJER, P. StARosta (red.), Wokót socjologii przestrzeni, Łódź: Wydawnictwo Uniwersytetu Łódzkiego 2004, s. 36.

${ }^{6}$ H. Lefebvre, The Production of Space, Maiden-Oxford-Carlton: Blackwell Publishers 1991, s. 32. Patrz też: B. JAŁOWIECKI, M. SZCZEPAŃSKI, Miasto i przestrzeń w perspektywie socjologicznej, Warszawa: Wydawnictwo Naukowe Scholar 2006, s. 31.

${ }^{7}$ B. JAŁOWIECKI, Społeczne wytwarzanie przestrzeni, Warszawa: Wydawnictwo Naukowe Scholar 2010, s. 21.

${ }^{8}$ M. Eliade, Sacrum i profanum, Warszawa: Wydawnictwo KR 1999, s. 16. 
pełne ucieleśnienie późnośredniowiecznego obrazu świata i stanowi syntezę egzystencjalnych znaczeń tego okresu" ${ }^{9}$. Z kolei inny zestaw symboli i wartości kulturowych znajduje swe uobecnienie w również wertykalnej budowli, jaką jest dwudziestowieczny korporacyjny drapacz chmur. Jest on wyrazem triumfu kapitalistycznej racjonalności, uniwersalności, funkcjonalności i stechnicyzowania ${ }^{10}$. Podobnie w skali mikro - natychmiast rzuca się w oczy różnica funkcji, a przede wszystkim stylów życia i wartości wyznawanych przez użytkowników jednoizbowej chaty epoki przedindustrialnej, w której niepodzielona wspólna przestrzeń stanowi egzemplifikację plebejskiej, „,niecywilizowanej" i opartej na prostym podziale pracy kultury tradycyjnej, w porównaniu do wyposażonego w gabinet, pokój dzienny, sypialnie, pokój dziecięcy i tym podobne współczesnego domu przedstawicieli klasy średniej ${ }^{11}$. Warto w tym miejscu przypomnieć, że na symboliczny i aksjologiczny wymiar przestrzeni już w 1938 roku zwracał uwagę Florian Znaniecki, pisząc: „Podmioty ludzkie nigdy nie doświadczają jakiejś powszechnej, obiektywnej, bezjakościowej, niezmiennej, nieograniczonej i nieograniczenie podzielnej przestrzeni. [...] Dane im są w doświadczeniu niezliczone «przestrzenie», jakościowo różnorodne, ograniczone, niepodzielne, zmienne, a przy tym dodatnio albo ujemnie oceniane" 12 .

Niejako w podsumowaniu powyższych zdań Bohdan Jałowiecki zauważa, że symboliczny i funkcjonalny charakter przestrzeni implikuje trojaki rodzaj działań przestrzennych: „Po pierwsze, mamy praktyki przestrzenne uwarunkowane sposobem produkcji i panującą ideologią, w toku których przestrzeń zostaje wytworzona. Po drugie, mamy do czynienia z naznaczaniem przestrzeni, czyli nadawaniem poszczególnym formom przestrzennym swoistego znaczenia, zgodnie z panującymi stosunkami społecznymi i ideologią [...]. Po trzecie wreszcie, występuje proces przyswajania przestrzeni, w którego toku jednostki i grupy społeczne zarówno adaptują się do istniejącej przestrzeni, jak i przestrzeń adaptują do siebie i swoich wyobrażeń, wartości i potrzeb poprzez jej naznaczanie, a więc modyfikowanie spontaniczne i na ogół w sposób niesformalizowany" "13. W dalszej części swojego wywodu Jałowiecki wskazuje na cztery zasadnicze determinanty, które warunkują wytwarzanie

\footnotetext{
${ }^{9}$ Ch. Norberg-Schulz, Znaczenie w architekturze Zachodu, Warszawa: Murator 1999, s. 111.

${ }^{10}$ Ch. JenCKs, Architektura postmodernistyczna, Warszawa: Arkady 1987, s. 14-15.

11 Por. N. Elias, Przemiany obyczajów w cywilizacji Zachodu, Warszawa: Państwowy Instytut Wydawniczy 1980; É. DURKHEIM, O podziale pracy społecznej, Warszawa: PWN 1999.

${ }^{12}$ F. ZNANIECKI, Socjologiczne podstawy ekologii ludzkiej, ,Ruch Prawniczy, Ekonomiczny i Socjologiczny" 1938, z. 1, s. 91.

${ }^{13}$ B. JAŁOWIECKI, Społeczne wytwarzanie przestrzeni, s. 24-25.
} 
określonej formy przestrzeni społecznej. Są to: po pierwsze, przyroda pojmowana jako przeszkoda, ale i zasób; po wtóre, określony poziom rozwoju technicznego i technologicznego (siły wytwórcze); po trzecie, stosunki panowania i podległości w aspekcie ekonomicznym, politycznym i ideologicznym; po czwarte, systemy wartości i wzory kulturowe charakterystyczne dla danego społeczeństwa oraz dominująca ideologia ${ }^{14}$.

W każdych czasach i pod każdą szerokością geograficzną można wskazać te grupy: klasy, warstwy oraz kategorie społeczne i zawodowe, których działalność oraz „siła kreacji” wywierają znaczący wpływ na kształt i charakter przestrzeni społecznej. Do głównych aktorów wytwarzających społeczną przestrzeń współczesnych społeczeństw (wraz z jej ekonomicznymi, kulturowymi i społecznymi implikacjami) należą z pewnością przedsiębiorcy, menedżerowie oraz interesariusze biznesowi (np. inwestorzy giełdowi). W dalszej części tekstu zostanie zatem przedstawiona krótka charakterystyka przekształceń przestrzeni społecznej $\mathrm{w}$ Polsce $\mathrm{z}$ naciskiem na te przestrzenie i miejsca, które stanowią środowisko klasy biznesu lub mają bezpośredni i pośredni wpływ na sposób realizacji interesów, a także na postawy, wartości i styl życia aktorów świata biznesu ${ }^{15}$.

\section{PRZEKSZTAŁCENIA PRZESTRZENI SPOŁECZNEJ W POLSCE W KONTEKŚCIE DZIAŁALNOŚCI BIZNESOWEJ}

Rok 1989 jest powszechnie uważany za cezurę w powojennej historii Polski. I tak jest $\mathrm{w}$ istocie. Trzeba jednak pamiętać, że klasa biznesu nie wyrosła „na surowym korzeniu”. Powojenna Polska to kraj co prawda zapóźniony w stosunku do Zachodu, w znacznym stopniu zniszczony w toku działań wojennych, o silnych tradycjach agrarnych, jednak w porównaniu z innymi „krajami demokracji ludowej” - o silnych tradycjach przedsiębiorczości. Ustawa nacjonalizacyjna z 3 stycznia 1946 roku o przejęciu na własność Państwa podstawowych gałęzi gospodarki narodowej likwidowała, rzecz jasna, wiele przedsiębiorstw prywatnych, pozostawiając jednak w rękach dotychczasowych właścicieli zakłady zatrudniające do 50 pracowników na zmianę (w niektórych przypadkach nawet do 200$)^{16}$. Natomiast próby skolektywizo-

\footnotetext{
14 Tamże, s. 39-44.

15 Tezy zaprezentowane w niniejszym artykule stanowiły kontekst badań prowadzonych przez autora i zostały włączone do książki: W. DYMARCZYK, Przestrzenny wymiar karier menedżerów i przedsiębiorców. Analiza socjologiczna, Łódź: Wydawnictwo Uniwersytetu Łódzkiego 2018.

${ }^{16}$ Dziennik Ustaw Rzeczpospolitej Polskiej, O przejęciu na wtasność Państwa podstawowych gatęzi gospodarki narodowej, http://dziennikustaw.gov.pl/du/1946/s/3/17,1946 (dostęp 2.02.2017)
} 
wania rolnictwa na masową skalę powiodły się jedynie częściowo. Realny socjalizm odcisnął jednak swoje niezatarte piętno na przestrzeni dużych i małych ośrodków miejskich oraz na samym biznesie - jego formach, skali oraz na sposobach zamieszkiwania, wzorach konsumpcji przedsiębiorców i menedżerów. Należy tu zwrócić uwagę na kilka kluczowych cech i zjawisk:

1. Rozdrobnienie rodzimego biznesu, jego wysokie opodatkowanie, bariery administracyjne i permanentna „niepewność jutra”, wszystko to skutkowało między innymi brakiem lub bardzo ograniczonymi inwestycjami w rozwój i rozbudowę prywatnych przedsiębiorstw. Ponadto przedsiębiorca czuł się pewniej, gdy jego firma znajdowała się bezpośrednio pod czujnym okiem właściciela. W drobnym biznesie regułą było w zasadzie sąsiadowanie budynków gospodarczych z mieszkalnymi lub unifikowanie ich funkcji pod jednym dachem. Niewielka skala działania była jednocześnie barierą dla wyłonienia się warstwy menedżerów sektora prywatnego.

2. Powstanie dużych, często przeskalowanych $\mathrm{w}$ porównaniu $\mathrm{z}$ realnymi potrzebami gospodarczymi, państwowych przedsiębiorstw produkcyjnych wraz z towarzyszącymi im nowymi ośrodkami miejskimi lub dużymi osiedlami, będącymi przeważnie „modyfikacją modernistycznej ideologii i doktryny miasta kapitalistycznego", czyli wypadkową projektów Le Corbusiera, Bauhausu czy grupy De Stijl ${ }^{17}$. W warstwie społecznej skutkowało to między innymi współzamieszkiwaniem dzielnicy czy osiedla przez przedstawicieli diametralnie odmiennych klas i warstw społecznych: robotników i chłoporobotników, inteligencji, menedżerów, a raczej zarządców przedsiębiorstw, a w konsekwencji - pewną homogenizacją stylów i warunków życia w obrębie wspomnianych grup, ale również nieuniknionych antagonizmów.

3. Upośledzenie przestrzeni konsumpcji oraz permanentny deficyt przestrzeni mieszkalnych oraz uniformizacja praktyk zamieszkiwania: podobnej kubatury powstających mieszkań, ich słabej jakości, dezindywidualizacji i standaryzacji wyposażenia. Jednocześnie, po okresie stalinizmu, uczynienie $\mathrm{z}$ faktu posiadania mieszkania i często reglamentowanych elementów jego wyposażenia wyróżnika pozycji społecznej i zawodowej ${ }^{18}$. Upośledzenie, o którym tu mowa, przejawiało się przykładowo również $\mathrm{w}$ dominacji zbiorowych i egalitaryzujących form

17 B. JAŁOWIECKI, M. SZCZEPAŃSKI, Miasto i przestrzeń w perspektywie socjologicznej, s. 167. „W wytwarzaniu przestrzeni produkcji można obserwować trzy niespójne tendencje: po pierwsze, występuje niewątpliwa dążność [...] do wyrównywania dysproporcji przestrzennych w uprzemysłowieniu kraju; po drugie, lokowanie wielkich zakładów przemysłowych w dużych miastach w celu zrównoważenia ich struktury klasowej; i wreszcie po trzecie, umieszczanie nowych fabryk w już istniejących okręgach przemysłowych w celu zyskania efektów aglomeracyjnych". B. JAŁOWIECKI, Spoteczne wytwarzanie przestrzeni, s. 224.

${ }^{18}$ M. JEwDokimow, Zmiany spotecznych praktyk zamieszkiwania, Warszawa: Wydawnictwo Uniwersytetu Kardynała Stefana Wyszyńskiego 2011, s. 138-150. 
wypoczynku i rekreacji (np. FWP), a w mniejszym stopniu prywatnych inwestycji rekreacyjnych (tzw. dacze) ${ }^{19}$.

4. Intensywność i skala działań biznesowych limitowana była również poprzez stan infrastruktury transportowej. Istniała zatem względnie gęsta sieć połączeń kolejowych, jako najbardziej wspieranej (bo „egalitaryzującej”) przez ówczesnych decydentów formy transportu, przy jednoczesnym niedorozwoju komunikacji drogowej i lotniczejej ${ }^{20}$. Przy czym należy zauważyć, że zasięg podejmowanych podróży ograniczał się w przeważającym stopniu do obszaru kraju. Wyjazdy zagraniczne (zawodowe i prywatne) były kosztowne i co ważniejsze reglamentowane, co wraz z innymi formami kontroli obywateli, w tym ich działalności gospodarczej, skutecznie ograniczało możliwości rozwijania kooperacji i inwestowania w obszarze biznesu. $Z$ drugiej strony ci, którzy dzięki przychylności władzy, koneksjom rodzinnym czy uporowi, mogli przekraczać granice, zyskiwali szansę wzbogacenia się i nawiązania sieci relacji przydatnych w czasach, gdy gorset ograniczeń związanych z rozwijaniem prywatnego biznesu uległ poluzowaniu, a następnie zniknął.

„Wielka zmiana”, czyli przełom lat osiemdziesiątych i dziewięćdziesiątych ubiegłego wieku oznaczał włączenie Polski w obieg światowego systemu gospodarki kapitalistycznej. Nie nastąpiło to jednak w jednej chwili, a tak zwany „okres przejściowy” czy też transformacyjny można w interesującym autora tego tekstu aspekcie przestrzeni społecznej scharakteryzować w następujący sposób:

1. Lawinowy rozwój małych przedsiębiorstw, powstających w spontaniczny, ale i dość chaotyczny sposób (często wbrew ładowi urbanistyczno-architektonicznemu). Jednocześnie ów gwałtowny wzrost przestrzeni spontanicznego biznesu okazał się naturalnym środowiskiem dla kształtowania się i rozwoju klasy przedsiębiorców typu self-made man, a po pewnym czasie również klasy profesjonalnych menedżerów ${ }^{21}$.

${ }^{19}$ B. JAŁOWIECKI, Spoteczne wytwarzanie przestrzeni, s. 249-253.

20 „Po II wojnie światowej Polska posiadała łącznie $160 \mathrm{~km}$ autostrad, a w momencie rozpoczęcia procesu transformacji ustrojowo-gospodarczej, czyli na przełomie lat 80. i 90 . minionego stulecia, niewiele więcej, bo 210 km”. A. SEREBEŃSKA, Polskie drogi: Zapał rzadowych planów studzit brak środków cz. I, http://www.rynekinfrastruktury.pl/wiadomosci/polskiedrogi-zapal-rzadowych-planow-studzil-brak-srodkow-cz-i-56677.html, 2016 (dostęp 2.02.2017). O zapóźnieniu komunikacji lotniczej dobitnie świadczy fakt, że Międzynarodowy Dworzec Lotniczy na Okęciu został otwarty dopiero 5 maja 1969. W tym też dniu odbyło się pierwsze w historii lotnictwa cywilnego w Polsce lądowanie maszyny o napędzie odrzutowym. P. KARWIŃSKI, 80 lat warszawskiego lotniska, http://www.epwa.pl/index.php?option=com_content\& view=article\&id=1838, 2014 (dostęp 5.02.2017).

${ }^{21}$ Por. K. JASIECKI, Elita biznesu w Polsce: drugie narodziny kapitalizmu, Warszawa: IFiS PAN 2002. W. DYMARCZYK, Temporalny wymiar karier menedżerskich, Katowice: Wydawnictwo Naukowe „Śląsk” 2008. P. SARZYŃSKI, Wrzask w przestrzeni. Dlaczego w Polsce jest tak brzydko?, Warszawa: Biblioteka Polityki 2012, s. 51-52. 
2. Otwarcie granic, a co za tym idzie - gwałtowny rozwój ponadlokalnych i międzynarodowych (początkowo głównie handlowych) kontaktów biznesowych, zwłaszcza w wymiarze mikro, czego najlepszą egzemplifikacją stały się przygraniczne bazary i gigantyczne targowiska (np. Stadion X-lecia, podłódzki Tuszyn) $)^{22}$.

3. Masowe uwłaszczenie nomenklatury poprzez prywatyzację dochodowych lub przedstawiających materialną wartość przedsiębiorstw państwowych ${ }^{23}$. Realizowanie przez nomenklaturowych przedsiębiorców/menedżerów dwojakich ścieżek kariery, polegających na eksploatowaniu przedsiębiorstwa i przenoszeniu jego zasobów do własnych firm lub (rzadziej) na profesjonalizacji zarządzania (i własnych umiejętności) w dotychczasowych organizacjach ${ }^{24}$. Ostatecznie tam, gdzie ,polityczny” menedżer okazał się sprawnym zarządcą, rychło różnica pomiędzy wizerunkiem i sposobem działania przejętej firmy a organizacji zagranicznej lub wyrosłej ze spontanicznej inicjatywy ulegała zatarciu. Z kolei w przypadku właścieli/menedżerów „, n nadania”, którzy nie znaleźli profesjonalnego lub politycznie znaczącego sponsora, sytuacja wygladała inaczej - spektakularne upadki przejętych firm nie należały bynajmniej do rzadkości (np. Igloopol, GTKI).

4. Wejście na polski rynek obcych inwestorów korporacyjnych i upowszechnianie się zachodnich standardów organizacji pracy - w wymiarze przestrzennym polegających między innymi na modernizacji i racjonalizacji produkcji czy dystrybucji, promocji wizerunku poprzez inwestycje w prestiżowe lokalizacje i budynki, design, reklamę, PR i dress code oraz na przearanżowaniu powierzchni firmowych/biurowych na wzór obowiązujących trendów lub mód (np. boksy ${ }^{25}$. W wymiarze ludzkim coraz silniejszy nacisk na kształtowanie menedżera typu professions ${ }^{26}$. Jednocześnie gros inwestycji zagranicznych można w owym czasie określić jako offshoring, polegających na przenoszeniu pewnych procesów biznesowych do Polski w celu obniżenia

\footnotetext{
22 E. KLIMA, J. ZAJĄCZKOWSKI, Handel bazarowy (targowiskowy) w Polsce w latach 19952006, „Space-Society-Economy” 2008, nr 8, s. 143-154.

23 J. Tittenbrun, $Z$ deszczu pod rynnę: studium polskiej prywatyzacji, Poznań: Zysk i S-ka 2007.

${ }^{24}$ K. JASIECKI, Elita biznesu w Polsce: drugie narodziny kapitalizmu.

25 Por. J. Schlosser, The Great Escape, „Fortune Magazine” 2006, nr 5(153), s. 107.

${ }^{26}$ Por. M. Burrage, R. Torstendahl, Professions in Theory and History. Rethinking the Study of the Professions, London, New Dehli: SAGE Publications 1990. D. JEMIELNIAK, Kultura: zawody i profesje, „Prace i Materiały ISM (Instytut Studiów Międzynarodowych)” SGH 2005, nr 32, s. 7-22.
} 
kosztów (np. produkcji i usług) przy jednoczesnym pozostawieniu ośrodków decyzyjnych poza krajem ${ }^{27}$.

5. Spektakularne otwarcie w 1991 roku Giełdy Papierów Wartościowych w Warszawie ${ }^{28}$ oraz dynamiczny rozwój sektora finansów i usług okołobiznesowych oraz początek kształtowania się biznesowego city w centrach największych miast i aglomeracji. Faktycznie, twory te można określić jako mniej lub bardziej udane kopie centrów innych europejskich stolic, lecz mimo to w latach 90. była to nowa jakość w polskim krajobrazie. Równocześnie i w związku z powyższym następuje wówczas dalsze różnicowanie się klasy menedżerów m.in. poprzez wyłonienie się grup specjalistów operujących głównie w obszarze finansów: analityków, traderów, doradców itp. Analogicznie rzecz miała się w przypadku przedsiębiorców, gdzie obok producentów i dystrybutorów wyodrębniła się grupa profesjonalnych inwestorów operujących najczęściej wirtualnym pieniądzem. W tym czasie wykształciła się również grupa urzędników/menedżerów, którą można określić „emisariuszami do strefy euro"29.

6. Rozwarstwianie się społeczeństwa pod względem dochodu ${ }^{30}$, a co za tym idzie - postępujące różnicowanie się klas i warstw społecznych pod względem stylu życia, dostępu do dóbr i usług, aspiracji i edukacji oraz sposobów spędzania czasu i warunków mieszkaniowych (np. podmiejskie budownictwo jednorodzinne i rezydencjalne) $)^{31}$.

7. Pojawienie się nowych form masowej, a także elitarnej rozrywki i rekreacji (np. kluby golfowe, wycieczki w najdalsze zakątki świata) oraz przestrzeni realizacji praktyk biznesowych poza firmą ${ }^{32}$ - infrastruktury okołobiznesowej

${ }^{27}$ B. JAŁOWIECKI, Społeczne wytwarzanie przestrzeni, s. 274.

${ }^{28} \mathrm{~W}$ momencie uruchomienia na Giełdzie Papierów Wartościowych w Warszawie notowanych było 9 spółek. Według stanu z października 2017 notowanych jest na niej 477 przedsiębiorstw, w tym 50 zagranicznych, Statystyki GPW, https://www.gpw.pl/statystyki-gpw, 2017 (dostęp 5.10.2017).

${ }^{29}$ W. DYMARCZYK, Temporalny wymiar karier menedżerskich, s. 73-74.

${ }^{30}$ Według danych Banku Światowego nierówności społeczne w Polsce mierzone wskaźnikiem Giniego u progu niepodległości - w 1989 r. - wynosiły 25 pkt. „Od początku lat 90. systematycznie rosły, by osiągnąc szczyt w latach 2002-2005, kiedy według dostępnych danych oscylowały wokół 34-35 pkt”. P. ARAK, P. ŻAKOWIECKI, Polska to kraj przeciętnych nierówno$s c i$, „Obserwator finansowy”, https://www.obserwatorfinansowy.pl/tematyka/makroekonomia/ polska-to-kraj-przecietnych-nierownosci/, 2015 (dostęp: 22.02.2017).

${ }^{31}$ Por. M. SAdura, P. SAdurA, Style życia i porzadek klasowy w Polsce, Warszawa: Wydawnictwo Naukowe Scholar 2012.

${ }^{32}$ Sztandarowym przykładem przestrzeni rekreacyjno-biznesowej jest pole golfowe. „Pierwszym polem zostało First Warsaw Golf \& Country Club, założone w 1992 roku w Rajszewie pod Warszawą. [...] W 1993 roku powstały dwie organizacje, mające na celu promocje golfa w naszym kraju. Polski Związek Golfa - zrzeszający amatorów i PGA Polska”, M. SŁOwIK, Golf w Polsce, http://livingroom24.pl/artykul/lifestyle/golf-w-polsce, b.d.w. (dostęp 2.02.2017). 
(np. sale konferencyjne, ośrodki szkoleniowe, miejsca dedykowane organizacjom i stowarzyszeniom zrzeszającym przedsiębiorców i menedżerów).

8. Coraz głębsze upośledzenie transportu kolejowego oraz gwałtowny rozwój motoryzacji przy jednoczesnym nadal występującym niedorozwoju infrastruktury drogowej. Systematyczny, choć mało dynamiczny rozwój transportu lotniczego. Przy czym trendy te zaczęły ulegać zmianie już w drugiej połowie lat 90., o czym będzie mowa dalej.

Koniec lat dziewięćdziesiątych i początek obecnego stulecia charakteryzuje się kontynuacja pewnych trendów z okresu przejściowego (np. postępujące rozwarstwianie się społeczeństwa i różnicowanie stylów życia czy utrzymywanie prymatu inwestycji zagranicznych typu offshoring), lecz również wykrystalizowaniem się nowych tendencji w zakresie społecznego wytwarzania i użytkowania przestrzeni, w tym przestrzeni biznesu:

1. Wzrost rodzimych przedsiębiorstw, których skala i zasoby pozwoliły na inwestycje (głównie w usługach, przetwórstwie przemysłowym, sektorze finansowym) w ramach innych obszarów geograficznych - przede wszystkim w krajach UE, gdzie według Ministerstwa Rozwoju w 2014 roku blisko 3/4 polskiego kapitału inwestycyjnego lokowane było w państwach Unii, ale też coraz częściej kapitał ten inwestowany jest poza obszarem wspólnoty ${ }^{33}$.

2. Rozpoczęta $\mathrm{w}$ dobie transformacji dalsza deindustrializacja przestrzeni zurbanizowanych, w tym przeniesienie ciężaru inwestycji zagranicznych (i krajowych) ze sfery przemysłu na sferę usług ${ }^{34}$.

3. Powstanie w głównych aglomeracjach Polski nowych lub rewitalizowanych powierzchni biurowych, a w efekcie przekształcanie się (głównie) centrów miast w obszary administracyjno-biznesowe. Przestrzenie te nabywaja niekiedy charakteru wyizolowanych z tkanki miejskiej i odspołecznionych przestrzeni prywatnych lub quasi-prywatnych i wraz ze zlokalizowanymi na obrzeżach miast lub poza miastami terenów pełniących czysto techniczne funkcje (np. wielkie kompleksy magazynowe, centra serwisowe), które można określić mianem nie-miejsc ${ }^{35}$.

\footnotetext{
${ }^{33}$ Ministerstwo Rozwoju, Departament Strategii Rozwoju, Polskie bezpośrednie inwestycje zagraniczne w 2014 roku, https://danepubliczne.gov.pl/dataset/8ae6b6b8-8eed-4936-8b0c-f4b 972dabd8c/resource/e7011897-44fb-491f-83d5-c6f06670edd6/download/Polskieinwestycjebezpo srednie2014.pdf, 2016 (dostęp 5.02.2017). W 2015 głównymi handlowymi partnerami Polski były: Niemcy (import 22,9\% obrotów, eksport 27,1\%), Chiny (import 11,6\%), Wielka Brytania (eksport 6,7\%), Rosja (import 7,3\%), Czechy (eksport 6,6\%), Główny Urząd Statystyczny, RocznikStatystycznyHandluZagranicznego, https://danepubliczne.gov.pl/dataset/eea68e82-c92f4e11-a2a8-b48ee9eb2a6e/resource/25abafbc-6563-4bb1-adde-731b76ba827d/download/roczniksta tystycznyhandluzagranicznego2016.pdf, 2016 (dostęp: 03.03.2017).

${ }^{34}$ B. JAŁOWIECKI, Społeczne wytwarzanie przestrzeni, s. 278-283.

${ }^{35}$ M. AugÉ, Nie-miejsca. Wprowadzenie do antropologii hipernowoczesności, Warszawa:
} 
4. W obszarze konsumpcji dynamiczny rozwój sieci handlowych i multifunkcyjnych centrów handlowo-rozrywkowych, a także zróżnicowanej pod względem jakości i w porównaniu z minionym okresem szerokiej bazy hotelowej. Jednocześnie marginalizacja tradycyjnych placówek handlowych ${ }^{36}$. W tym kontekście wzrost znaczenia menedżerów i specjalistów ds. zarządzania projektami i współpracy biznesowej, logistów, menedżerów rozrywki, rekreacji i szeroko pojmowanej opieki zdrowotnej.

5. Niemal powszechna $w$ środowisku pracy oraz $w$ miejscach prywatnych, a coraz częściej też publicznych dostępność Internetu i usług z nim związanych. Przeniesienie wielu transakcji biznesowych oraz różnego typu usług w przestrzeń wirtualną ${ }^{37}$. Powstanie wielu profesjonalnych, a także zogniskowanych wokół wspólnych zainteresowań i rozrywki społeczności internetowych oraz stale rosnący popyt na specjalistów i menedżerów usług informatycznych ${ }^{38}$.

6. Wraz z postępującą integracją gospodarczą i polityczną (m.in. wejście do UE) pojawia się coraz większa „wrażliwość” na globalne trendy w obszarze makroekonomicznym, co przekłada się między innymi na coraz silniejsze uzależnianie planów i decyzji inwestycyjnych (biznesowych i prywatnych) od koniunktury na rynkach światowych ${ }^{39}$.

PWN 2012. E. SEKUŁA, Przestrzeń szeroko zamknięta, „Studia Regionalne i Lokalne” 2008, nr 3, s. 21-32.

${ }^{36}$ M. SMAGACZ, Galeria, centrum, center - o tożsamości wspótczesnego miejsca handlu, Autoportret, „Pismo o dobrej przestrzeni. Przestrzenie handlu” 2006, nr 2, s. 8-11. B. JAŁOWIECKI, Spoteczne wytwarzanie przestrzeni, s. 286-291.

37 Według danych Głównego Urzędu Statystycznego w 2016 roku dostęp do Internetu posiadało 93,7\% przedsiębiorstw i najczęściej korzystały one z łączy szerokopasmowych (93,2\%). W tym samym roku dostęp do Internetu miało 80,4\% gospodarstw domowych, Główny Urząd Statystyczny, Spoteczeństwo informacyjne w Polsce w 2016 r., file://C:/Users/Asus/ Downloads/si__sygnalna_2016\%20(2).pdf (dostęp 10.03.2017).

${ }^{38}$ W 2015 roku Fundacja Kronenberga przeprowadziła ogólnopolskie badanie polskich startupów, z którego wynika, że połowa tychże firm zajmuje się produkcją oprogramowania i operuje najczęściej w branżach aplikacji mobilnych handlu elektronicznego (e-Commerce) i usług (Web Service), A. Skala, E. KruczKowska, M. Olczak, Polskie startupy. Raport 2015, http://www.citibank.pl/poland/kronenberg/polish/files/Startup_Poland_raport_2015.pdf, 2015, s. 17 (dostęp 2.02.2017). Według raportu Hays Poland wśród dziesięciu najczęściej poszukiwanych zawodów w 2016 roku dwie pozycje zarezerwowane są dla menedżerów i specjalistów w obszarze E-Commerce i programowania, Hays Poland, Top 10 zawodów w 2016, http://www.hays.pl/notatki-prasowe-hays/top-10-zawod\%C3\%B3w-w-2016-wg-hays-poland-15 58364, 2016 (dostęp 20.06.2016).

${ }^{39}$ Wyrazem coraz powszechniejszej potrzeby dostępu do bieżących informacji biznesowych i gospodarczych było powstanie rodzimych całodobowych serwisów; w 2004 roku TV Biznes (obecnie Polsat News+), a w 2013 roku popularnego TVN24 Bis. 
7. Postępująca segregacja dochodowo-przestrzenna, przejawiająca się między innymi w procesach:

a) suburbanizacji, czyli opuszczania przez zamożniejsze warstwy społeczne terenów miejskich i osiedlania się poza granicami miasta ${ }^{40}$ oraz gentryfikacji, najczęściej przybierającej postać zasiedlania przez ludzi o wysokim statusie społeczno-ekonomicznym uprzednio odnowionych dzielnic lub osiedli ${ }^{41}$.

b) coraz powszechniejszym fenomenie osiedli zamkniętych (gated communities), również skupiających dobrze sytuowanych członków społeczeństwa, przy czym „moda na grodzenie" ${ }^{, 42}$ przenika także do mniej zamożnych grup społecznych ${ }^{43}$.

c) powolnej, lecz systematycznej dezurbanizacji, czyli wyludniania się miasta centralnego wskutek oddziaływania powyższych procesów, a także z powodu niżu demograficznego i dość znacznej emigracji, zwłaszcza ludzi młodych.

8. Zdecydowanego zwiększenia w ostatniej dekadzie liczby oraz długości autostrad i dróg szybkiego ruchu. Podobnie miało miejsce zwiększenie liczby połączeń i portów lotniczych ${ }^{44}$.

${ }^{40}$ K. KAJdANEK, Pomiędzy miastem a wsia. Suburbanizacja na przyktadzie osiedli podmiejskich Wrocławia, Kraków: Zakład Wydawniczy „Nomos” 2011; K. KAJDANEK, Dom na suburbiach. Ideat podmiejskiego zamieszkiwania a strategie udomowienia, w: M. ŁUKASIUK, M. Jewdokimow (red.), Socjologia zamieszkiwania, Warszawa: Wydawnictwo Naukowe Sub Lupa 2014, s. 181-214.

${ }^{41}$ Por. J. GRZESZCZAK, Gentryfikacja osadnictwa. Charakterystyka, rozwój koncepcji badawczej, Monografie IGiPZ PAN, nr 11, Warszawa 2010. J. JAKÓBCZYK-GRYSZKIEWICZ (red.), Procesy gentryfikacji w mieście, Łódź: Wydawnictwo Uniwersytetu Łódzkiego 2012.

${ }^{42} \mathrm{~W}$ samej tylko Warszawie w początkach drugiej dekady XXI wieku było około 400 grodzonych osiedli, M. WyBIERALSKI, Polska obsesja grodzenia: osiedla, parki a nawet śmietniki za ptotem, „Gazeta Wyborcza” wydanie internetowe z dn. 13.06.2013 http://wyborcza.pl/1,75 478,140 97937,Polska_obsesja_grodzenia_Za_plotem_osiedla_parki_html, 2013 (dostęp 20.06.2017).

${ }^{43}$ B. JAŁOWIECKI, W. ŁUKOWSKI (red.), Gettoizacja polskiej przestrzeni miejskiej, Warszawa: Wydawnictwo Naukowe „Scholar”, Wydawnictwo SWPS „Academica” 2007, M. LEWICKA, K. ZABORSKA, Osiedla zamknięte - czy istnieje alternatywa?, „Kolokwia Psychologiczne” 2007, $\mathrm{nr}$ 16, s. 135-152, J. GĄDECKI, Osiedla grodzone w Polsce - analiza dyskursu, Wrocław: Wydawnictwo Uniwersytetu Wrocławskiego 2009.

${ }^{44}$ Obecnie polska sieć autostrad mierzy ok. $1630 \mathrm{~km}$. Ponadto posiadamy ok. $1500 \mathrm{~km}$ dróg ekspresowych. Daje to w sumie ponad $3130 \mathrm{~km}$ tras szybkiego ruchu w standardzie spełniającym europejskie wymagania, A. SEREBEŃSKA, Polskie drogi: Zapat rzqdowych planów studzit brak środków cz. I, http://www.rynekinfrastruktury.pl/wiadomosci/polskie-drogi-zapalrzadowych-planow-studzil-brak-srodkow-cz-i-56677.html, 2016 (dostęp 2.02.2017); W 1989, ostatnim roku PRL-u liczba pasażerów linii lotniczych wyniosła blisko 3118000, M. SERAFIN, Ćwierć wieku działalności PRL-u, http://www.prtl.pl/print,10543,1, 2012 (dostęp 2.02.2017). 


\section{KONKLUZJE}

Powyższa, dość ogólna relacja na temat przemian przestrzeni społecznej biznesu i ,jego okolic" wymaga komentarza wykraczającego poza dość oczywistą faktografię, jakkolwiek samą w sobie wymowną. Otóż, jak zauważył Marek Ziółkowski: „Dokonujące modernizacji społeczeństwo polskie jest w znacznej mierze społeczeństwem «naśladowczym»w stosunku do społeczeństw «przodujących». Tak jak używało się pojęcia «transformacja imitacyjna», tak też można mówić o «modernizacji imitacyjnej»"45. Problem jednak w tym, że „naśladujemy” wzory i rozwiązania pochodzące z co najmniej trzech, odległych od siebie w czasie, etapów rozwoju kapitalizmu, czyli, po pierwsze, etapu wczesnej nowoczesności - społeczeństwa przemysłowego, a zatem gospodarki opartej na regule wolnej konkurencji, akumulacji kapitału i aprecjacji działalności produkcyjnej rozumianej jako interes i moralne zobowiązanie. Po wtóre, etapu późnej nowoczesności, czyli postindustrialnej, rozwijającej sferę usług gospodarki. W tej formie rozwoju kapitalizmu konsumpcja staje się wartością centralną i jednym z najważniejszych regulatorów życia społecznego. Po trzecie, fazy ponowoczesności, charakteryzującej się dalszym wzrostem roli konsumpcji mającej zaspokajać stale rosnące nie tyle potrzeby, co pragnienia, ale jednocześnie ma tu miejsce zwrot, przynajmniej części społeczeństwa, w kierunku wartości postmaterialistycznych ${ }^{46}$. Chociaż w dzisiejszej dobie - ponad ćwierć wieku od wyborów 1989 roku - trudno mówić o społeczeństwie polskim jako zbiorowości w okresie transformacji, to jednak doświadczenie ,wielkiej zmiany” oraz oceny i porównania dokonywane przez uczestników przedstawionego dalej badania często zawierają wyraźny komponent komparatywny z minionym czasem. Po wtóre, wcale nie tak odległy realny socjalizm, a tym bardziej okres przemian ustrojowo-gospodarczych odcisnęły niezatarte piętno na materialnie, praktycznie i symbolicznie pojmowanych miejscach i przestrzeniach, w których i wobec których podejmują działania aktorzy biznesu i względem których wyrażają określone postawy i emocje.

W kontekście powyższych, wciąż w dużej mierze aktualnych, stwierdzeń warto zauważyć, że dokonujący się w ostatnim czasie prawicowo-konserwa-

W 2016 roku przez polskie lotniska przewinęło się 34186000; M. PIOTROWSKI, Polskie lotniska rosna $w$ site! W 2016 r. obstużyty ponad $34 \mathrm{mln}$ pasażerów!, https://www.fly4free.pl/polskielotniska-rosna-w-sile-w-2016-r-obsluzyly-ponad-34-mln-pasazerow/, 2017 (dostęp 2.02.2017).

${ }^{45}$ M. ZIóŁKowsKi, O różnorodności teraźniejszości. (Pomiędzy tradycja spuścizna socjalizmu, nowoczesnościa a ponowoczesnościa), „Kultura i Społeczeństwo” 1997, nr 4, s. 28.

${ }^{46}$ R. Inglehart, Changing Values, Economic Development and Political Change, „International Social Science Journal” 1995, nr 145, s. 379-403. 
tywny zwrot, obserwowany w krajach Europy Środkowej, w tym w Polsce, uzasadnia wątpliwość co do wyrażonego tu explicite i implicite przekonania o modernizacji naśladowczej, rozumianej jako „doganianie Zachodu” ${ }^{47}$. Odejście od modelu liberalnego w kierunku gospodarki w większym niż dotychczas stopniu kierowanej i uzasadnianej politycznymi względami, czyli „kapitalizmu państwowego" i etatyzmu, będzie zapewne mieć swoje implikacje również dla przekształceń przestrzeni społecznej. W interesującym nas wymiarze gospodarczym i biznesowym może oznaczać priorytet „sztandarowych” inwestycji opartych na krajowym kapitale państwowym i państwowo-prywatnym, a także transnarodowym (głównie przedsięwzięcia określane jako „strategiczne" i ich infrastruktura, np. Centralny Port Lotniczy, kanał na Mierzei Wiślanej, gazociąg Baltic Pipe itp.). Po wtóre, zmniejszenie inwestycji w projekty służące integracji ze „Stara Europa”, o charakterze proekologicznym, trzeci sektor i generalnie służące zaspokajaniu potrzeb postmaterialistycznych. Jedocześnie można spodziewać się, że nie zostaną uszczuplone, a nawet zyskaja rangę priorytetowych programy socjalne i służące „wyrównywaniu szans” (np. mieszkanie+, 500+, dalszy rozwój specjalnych stref ekonomicznych w obszarach dawniej określanych jako „Polska B”). Nastąpi też zapewne bezpośredni wzrost znaczenia i wpływów aktorów politycznych na kierunki rozwoju i konkretne decyzje gospodarcze tak na poziomie krajowym jak i lokalnym.

\section{BIBLIOGRAFIA}

AraK P., WóJCIK A., Polski kapitalizm. Jaki model realizujemy? „Polityka Insight”, https:// www.politykainsight.pl/gospodarka/ryzykaitrendy/_resource/multimedium/20104895, 2016 (dostęp 10.02.2017).

ARAK P. ŻAKOwIECKI P., Polska to kraj przeciętnych nierówności, „Obserwator finansowy”, https://www.obserwatorfinansowy.pl/tematyka/makroekonomia/polska-to-kraj-przecietnychnierownosci/, 2015 (dostęp 22.02.2017).

AugÉ M., Nie-miejsca. Wprowadzenie do antropologii hipernowoczesności, Warszawa: PWN 2012.

Burrage M., Torstendahl R., Professions in Theory and History. Rethinking the Study of the Professions, London, New Dehli: SAGE Publications 1990.

De Lauwe Ch., Paul H. i in., Paris et l'agglomération parisienne, Paris: Presses Universitaires de France 1952.

${ }^{47}$ K. JASIECKI, Nowe oblicze polskiego kapitalizmu?, „Zoon Politikon” 2015, nr 6. Patrz też: P. ARAK, A. WóJCIK, Polski kapitalizm. Jaki model realizujemy? „Polityka Insight”, https: //www.politykainsight.pl/gospodarka/ryzykaitrendy/_resource/multimedium/20104895,2016(dostęp 10.02.2017). 
De Lauwe Ch., Paul H., La vie quotidienne des familles ouvrčres, Paris: Presses Universitaires de France 1956.

DURKHEIM É., O podziale pracy społecznej, Warszawa: PWN 1999.

W. DYMARCZYK, Przestrzenny wymiar karier menedżerów i przedsiębiorców. Analiza socjologiczna, Łódź: Wydawnictwo Uniwersytetu Łódzkiego 2018.

DYMARCZYK W., Temporalny wymiar karier menedżerskich, Katowice: Wydawnictwo Naukowe „Śląsk” 2008.

Dziennik Ustaw Rzeczpospolitej Polskiej, O przejęciu na własność Państwa podstawowych gałęzi gospodarki narodowej, http://dziennikustaw.gov.pl/du/1946/s/3/17, 1946, (dostęp 2.02.2017).

Eliade M., Sacrum i profanum, Warszawa: Wydawnictwo KR 1999.

Elias N., Przemiany obyczajów w cywilizacji Zachodu, Warszawa: Państwowy Instytut Wydawniczy 1980.

GĄDECKI J., Osiedla grodzone w Polsce - analiza dyskursu, Wrocław: Wydawnictwo Uniwersytetu Wrocławskiego 2009.

Główny Urząd Statystyczny, Rocznik Statystyczny Handlu Zagranicznego, https://danepublicz ne.gov.pl/dataset/eea68e82-c92f-4e11-a2a8-b48ee9eb2a6e/resource/25abafbc-6563-4bb1-adde731b76ba827d/download/rocznikstatystycznyhandluzagranicznego2016.pdf, 2016 (dostęp 03.03.2017).

Główny Urząd Statystyczny, Społeczeństwo informacyjne w Polsce w 2016 r., file:///C:/Users /Asus/Downloads/si_sygnalna_2016\%20(2).pdf (dostęp 10.03.2017).

GRZESZCZAK J., Gentryfikacja osadnictwa. Charakterystyka, rozwój koncepcji badawczej, Monografie IGiPZ PAN, nr 11, Warszawa 2010.

Hays Poland, Top 10 zawodów w 2016, http://www.hays.pl/notatki-prasowe-hays/top-10-zawod \%C3\%B3w-w-2016-wg-hays-poland-1558364, 2016 (dostęp 20.06.2017).

INGLehart R., Changing Values, Economic Development and Political Change, „International Social Science Journal" 1995, nr 145, s. 379-403.

JAKÓBCZYK-GRYSZKIEWICZ J. (red.), Procesy gentryfikacji w mieście, Łódź: Wydawnictwo Uniwersytetu Łódzkiego 2012.

JAŁOWIECKI B., Społeczne wytwarzanie przestrzeni, Warszawa: Wydawnictwo Naukowe Scholar 2010.

JAŁOWIECKI B., SzCZEPAŃSKi M., Miasto i przestrzeń w perspektywie socjologicznej, Warszawa: Wydawnictwo Naukowe Scholar 2006.

JAŁOWIECKI B., ŁUKOWSKI W. (red.), Gettoizacja polskiej przestrzeni miejskiej, Warszawa: Wydawnictwo Naukowe „Scholar”, Wydawnictwo SWPS „Academica” 2007.

JASIECKI K., Elita biznesu w Polsce: drugie narodziny kapitalizmu, Warszawa: IFiS PAN 2002.

JASIECKI K., Nowe oblicze polskiego kapitalizmu?, „Zoon Politikon” 2015, nr 6.

JEMIELNIAK D., Kultura: zawody i profesje, „Prace i materiały ISM (Instytut Studiów Międzynarodowych)" SGH 2005, nr 32, s. 7-22.

JENCKS Ch., Architektura postmodernistyczna, Warszawa: Arkady 1987.

JEWDOKIMOW M., Zmiany społecznych praktyk zamieszkiwania, Warszawa: Wydawnictwo Uniwersytetu Kardynała Stefana Wyszyńskiego 2011.

KaJDANeK K., Pomiędzy miastem a wsią. Suburbanizacja na przykładzie osiedli podmiejskich Wrocławia, Kraków: Zakład Wydawniczy „Nomos” 2011.

KAJDANEK K., Dom na suburbiach. Ideał podmiejskiego zamieszkiwania a strategie udomowienia, w: M. ŁUKASIUK, M. JEWDOKIMOW (red.), Socjologia zamieszkiwania, Warszawa: Wydawnictwo Naukowe Sub Lupa 2014, s. 181-214.

KARWIŃSKI P., 80 lat warszawskiego lotniska, http://www.epwa.pl/index.php?option=com_co ntent\&view=article\&id=1838, $2014($ dostęp 5.02.2017). 
Klima E., ZaJĄCZKOWSKI J., Handel bazarowy (targowiskowy) w Polsce w latach 1995-2006, „Space-Society-Economy” 2008, nr 8, s. 143-154.

Lefebvre H., The Production of Space, Maiden, Oxford, Carlton: Blackwell Publishers 1991.

Lefebvre H., State, Space, World: Selected Papers, Minneapolis: Minnesota University Press 2009.

LEWICKA M., ZABORSKA K., Osiedla zamknięte - czy istnieje alternatywa?, „Kolokwia Psychologiczne" 2007, nr 16, s. 135-152.

MAJER A., Od idei przestrzeni społecznej do koncepcji czasoprzestrzeni, w: A. MAJER, P. STAROSTA (red.), Wokół socjologii przestrzeni, Łódź: Wydawnictwo Uniwersytetu Łódzkiego 2004.

Ministerstwo Rozwoju, Departament Strategii Rozwoju, Polskie bezpośrednie inwestycje zagraniczne w 2014 roku, https://danepubliczne.gov.pl/dataset/8ae6b6b8-8eed-4936-8b0c-f4b972 dabd8c/resource/e7011897-44fb-491f-83d5-c6f06670edd6/download/Polskieinwestycjebezpo srednie2014.pdf, 2016 (dostęp 5.02.2017).

NORBERG-SchUlZ Ch., Znaczenie w architekturze Zachodu, Warszawa: Murator 1999.

O'NeILl J., Sociology as a Skin Trade: Essays Towards a Reflexive Sociology, New York: Harper \& Row 1972.

Piotrowski M., Polskie lotniska rosną w siłę! W 2016 r. obsłużyły ponad 34 mln pasażerów!, https://www.fly4free.pl/polskie-lotniska-rosna-w-sile-w-2016-r-obsluzyly-ponad-34-mln-pa sazerow/, 2017 (dostęp 2.02.2017).

Sadura M., Sadura P., Style życia i porządek klasowy w Polsce, Warszawa: Wydawnictwo Naukowe Scholar 2012

SARZYŃSKI P., Wrzask w przestrzeni. Dlaczego w Polsce jest tak brzydko?, Warszawa: Biblioteka Polityki 2012.

SCHLOSSER J., The Great Escape, „Fortune Magazine” 2006, nr 153 (5), s. 107.

SEkUŁa E., Przestrzeń szeroko zamknięta, ,Studia Regionalne i Lokalne” 2008, nr 3, s. 21-32.

SERAFIN M., Ćwierć wieku działalności PRL-u, http://www.prtl.pl/print,10543,1, 2012 (dostęp 2.02.2017)

SEREBEŃSKA A., Polskie drogi: Zapał rządowych planów studził brak środków cz. I, http:// www.rynekirfrastruktury.pl/wiadomosci/polskie-drogi-zapal-rzadowych-planow-studzil-braksrodkow-cz-i-56677.html, 2016 (dostęp 2.02.2017).

Skala A., KruCZKowsKa E., OlCZAK M., Polskie startupy. Raport 2015, http://www.citiba nk.pl/ poland/kronenberg/polish/files/Startup_Poland_raport_2015.pdf, 2015 (dostęp 2.02.2017).

SŁowIK M., Golf w Polsce, http://livingroom24.pl/artykul/lifestyle/golf-w-polsce, b.d.w. (dostęp 2.02.2017).

SMAGACZ M., Galeria, centrum, center - o tożsamości współczesnego miejsca handlu, Autoportret, „Pismo o dobrej przestrzeni. Przestrzenie handlu” 2006, nr 2, s. 8-11.

SMERThurst P., The Postmodern Chronotype: Reading Space and Time in Contemporary Fiction, Amsterdam-Atlanta: Rodopi B.V. 2000.

Statystyki GPW, https://www.gpw.pl/statystyki-gpw, 2017 (dostęp 5.10.2017).

TitTEnBrun J., Z deszczu pod rynnę: studium polskiej prywatyzacji, Poznań: Zysk i S-ka, 2007.

WYBIERALSKI M., Polska obsesja grodzenia: osiedla, parki a nawet śmietniki za płotem, „Gazeta Wyborcza” wydanie internetowe z dn. 13.06.2013 http://wyborcza.pl/1,75478,14097937, Polska_obsesja_grodzenia_ZZ_plotem_osiedla__parki_.html, 2013 (dostęp 20.06.2017).

ZIóŁKOWSKI M., O różnorodności teraźniejszości. (Pomiędzy tradycją, spuścizną socjalizmu, nowoczesnością a ponowoczesnością), „Kultura i Społeczeństwo” 1997, nr 4, s. 19-48.

ZNANIECKI F., Socjologiczne podstawy ekologii ludzkiej, „Ruch Prawniczy, Ekonomiczny i Socjologiczny” 1938 , z. 1. 


\title{
HISTORYCZNE UWARUNKOWANIA DZIAŁAŃ BIZNESOWYCH W POLSCE Z PERSPEKTYWY KONCEPCJI PRZESTRZENI SPOŁECZNEJ
}

\author{
S t r e s z c z e n i e
}

Działania aktorów życia społecznego odbywają się w określonych kontekstach czasowych i przestrzennych. To, do czego dążą, jakie mają cele i szanse ich realizacji zależy m.in. od określonego poziomu rozwoju infrastruktury, techniki i technologii, otoczenia instytucjonalnego czy obowiązującej ideologii. Tematem niniejszego artykułu są główne uwarunkowania rozwoju biznesu w Polsce, poczynając od czasów powojennych do dnia dzisiejszego. Nawiązując do koncepcji przestrzeni społecznej, autor ukazuje przemiany środowiska rozumianego jako pewien zestaw założeń i determinantów rozwojowych i ich fizycznych emanacji, które na każdym etapie historycznym wpływały na wybór celów i charakter działań biznesowych. Ostatnią część artykułu stanowi refleksja nad możliwymi kierunkami rozwoju przestrzeni społecznej w Polsce.

Słowa kluczowe: przestrzeń społeczna; przedsiębiorczość; historia gospodarcza; socjologia przestrzeni.

\section{HISTORICAL CONDITIONS FOR BUSINESS ACTIVITIES IN POLAND FROM THE PERSPECTIVE OF THE SOCIAL SPACE CONCEPT}

\section{S u m m a r y}

The activities of social actors take place in specific temporal and spatial contexts. What are their goals and their chances of realization depend, inter alia, on the specific level of development of the infrastructure, technique and technology, institutional environment or preferred ideology. The subject of this article are the main conditions for the development of business in Poland, from the post-war period to the present day. Referring to the concept of social space, the author shows the transformations of the environment, understood as a set of assumptions and determinants of development and their physical emanations, which at every stage of history influenced the choice of goals and the nature of business activities. The final part of the article is a reflection on the possible directions of development of the social space in Poland.

Key words: social space; entrepreneurship; economic history; sociology of space. 